Dialysis, Dialyzers and Sorbents. Where Are We Going? 


\section{Contributions to Nephrology}

Vol. 133

Series Editors

G.M. Berlyne Beersheva/Brooklyn, N.Y.

C. Ronco Vicenza

KARGER 


\title{
Dialysis, Dialyzers and Sorbents
}

Where Are We Going?

\author{
Volume Editors \\ C. Ronco Vicenza \\ J.F. Winchester New York, N.Y.
}

53 figures, 16 in color, and 19 tables, 2001

KARGER $\begin{aligned} & \text { Basel } \cdot \text { Freiburg } \cdot \text { Paris } \cdot \text { London } \cdot \text { New York } \cdot \\ & \text { New Delhi } \cdot \text { Bangkok } \cdot \text { Singapore } \cdot \text { Tokyo } \cdot \text { Sydney }\end{aligned}$ 


\section{Claudio Ronco}

Department of Nephrology

St. Bortolo Hospital

I-36100 Vicenza (Italy)
James F. Winchester

RenalTech International

320 East 65 th Street, No. 116

New York, NY 10021 (USA)

Library of Congress Catalogin-in-Publication Data

Dialysis, dialyzers, and sorbents : where are we going? / volume editors, C. Ronco, J.F. Winchester,

p. ; cm. -- (Contributions to nephrology; vol. 133)

Includes bibliographical references and indexes.

ISBN 3805572255 (alk. paper : hardcover)

1. Hemodialysis. 2. Uremia. 3. Sorbents. I. Ronco, C. (Claudio), 1951- II. Winchester, James F.

III. Contributions to nephrology; v. 133.

[DNLM: 1. Renal Dialysis--methods. 2. Adsorption. 3. Hemoperfusion. 4. Renal Dialysis--instrumentation.

5. Renal Dialysis--trends. WJ 378 D53523 2001]

RC901.7.H45 D523 2001

617.4'61059--dc2

2001029613

Bibliographic Indices. This publication is listed in bibliographic services, including Current Contents ${ }^{\circledR}$ and Index Medicus

Drug Dosage. The authors and the publisher have exerted every effort to ensure that drug selection and dosage set forth in this text are in accord with current recommendations and practice at the time of publication. However, in view of ongoing research, changes in government regulations, and the constant flow of information relating to drug therapy and drug reactions, the reader is urged to check the package insert for each drug for any change in indications and dosage and for added warnings and precautions. This is particularly important when the recommended agent is a new and/or infrequently employed drug.

All rights reserved. No part of this publication may be translated into other languages, reproduced or utilized in any form or by any means, electronic or mechanical, including photocopying, recording, microcopying, or by any information storage and retrieval system, without permission in writing from the publisher.

CC Copyright 2001 by S. Karger AG, P.O. Box, CH-4009 Basel (Switzerland)

www.karger.com

Printed in Switzerland on acid-free paper by Reinhardt Druck, Basel

ISSN 0302-5144

ISBN 3-8055-7225-5 


\section{Contents}

VII Preface

Ronco, C. (Vicenza), Winchester J.F. (New York, N.Y.)

The Challenge for the New Millennium

1 Unmet Clinical Needs in Dialysis: What Can We Do?

Ritz, E.; Zeier, M. (Heidelberg)

10 New Technologies for Patients with End-Stage Renal Disease: The US Regulatory Perspective

Provost, M.C.; Meyers, C.M. (Rockville, Md.)

New Insights on the Pathogenesis of Uremia and Dialysis Morbidity

23 The Role of Middle Molecules in Uremia - Preliminary Report of an International Survey of Nephrologists and Scientists

Winchester, J.F.; Brady, J.A. (New York, N.Y.); Ronco, C. (Vicenza); Yousha, E.; Smith, A.; Clemmer, J.; Muller, T.E. (New York, N.Y.); La Greca, G. (Vicenza); Levin, N.W. (New York, N.Y.)

28 Are New Toxins Appearing on the Horizon? Hörl, W.H. (Vienna)

42 Redesigning the Map of Uremic Toxins Vanholder, R.; De Smet, R.; Lameire, N.H. (Ghent)

71 Reactive Carbonyl Compounds as Uremic Toxins

Miyata, T. (Kanagawa); Akhand, A.A. (Nagoya); Kurokawa, K. (Kanagawa); Nakashima, I. (Nagoya) 
Hemodialyzers

81 Haemodialysis Membranes: A Matter of Fact or Taste? Hoenich, N.A. (Newcastle/New York, N.Y.); Katopodis, K.P. (Ioannina)

105 New Developments in Hemodialyzers

Vienken, J. (Bad Homburg); Ronco, C. (Vicenza)

119 Computerized Selection of Membranes and Hemodialysers

Ronco, C. (Vicenza); Ghezzi, P.M. (Cuneo); Hoenich, N.A. (Newcastle/ New York, N.Y.); Delfino, P. (Cuneo)

Hemoperfusion Techniques and Sorbent Devices

131 History of Sorbents in Uremia

Winchester, J.F. (New York, N.Y.); Ronco, C. (Vicenza); Brady, J.A.; Clemmer, J.; Muller, T.E.; Davankov, V.; Tsyurupa, M.; Pavlova, L.; Pavlov, M.; Levin, N.W. (New York, N.Y.)

140 Adsorption Techniques and the Use of Sorbents Lameire, N.H.; De Vriese, A.S. (Ghent)

154 Characterization of Flow-Dynamic Pattern in a New Sorbent Cartridge for Combined Hemoperfusion-Hemodialysis

Polaschegg, H.D. (Köstenberg); Ronco, C.; Soli, M. (Vicenza)

166 First Clinical Experience with an Adjunctive Hemoperfusion Device Designed Specifically to Remove $\boldsymbol{\beta}_{\mathbf{2}}$-Microglobulin in Hemodialysis Ronco, C. (New York, N.Y./Vicenza); Brendolan, A. (Vicenza); Winchester, J.F.; Golds, E.; Clemmer, J. (New York, N.Y.); Polaschegg, H.D. (Köstenberg); Muller, T.E.; Davankov, V.; Tsyurupa, M.; Pavlova, L.; Pavlov, M. (New York, N.Y.); La Greca, G. (Vicenza); Levin, N.W. (New York, N.Y.)

174 Rationale for Combined Hemoperfusion/Hemodialysis in Uremia Winchester, J.F. (New York, N.Y.); Ronco, C. (Vicenza); Brady, J.A.

(New York, N.Y.); Brendolan, A. (Vicenza); Davankov, V.; Tsyurupa, M.; Pavlova, L.; Pavlov, M.; Clemmer, J. (New York, N.Y.); Polaschegg, H.D. (Köstenberg); Muller, T.E. (New York, N.Y.); La Greca, G. (Vicenza); Levin, N.W. (New York, N.Y.)

180 Use of Sorbents in Acute Renal Failure and Sepsis

Ronco, C.; Brendolan, A.; Dan, M.; Piccinni, P. (Vicenza); Bellomo, R. (Melbourne, Vic.); Wratten, M.L.; Inguaggiato, P.; Tetta, C. (Mirandola)

194 Author Index

195 Subject Index 


\section{Preface}

The treatment of end-stage renal disease patients has greatly evolved in the last decade. The original design of hemodialyzers has been partially modified to improve efficiency and performance. The membranes utilized for extracorporeal blood purification techniques have been synthetically generated or modified according to specific requirements. Further improvements have been achieved with the development of highly hemocompatible surfaces and components of the extracorporeal blood circuit. In the mean time, the availability of new devices and new membranes has led to the development of modern hemodialysis techniques in which clinical tolerance and high efficiency have significantly improved morbidity and mortality in hemodialysis patients. Nevertheless, the limitations imposed by hemodialysis have clearly emerged, especially from the long-term complications occurring in patients treated for several years. In this setting, new approaches are under evaluation. Since most of the long-term complications seem to be related to the chronic inflammation of ESRD patients and the progressive accumulation of middle-large molecules such as beta-2-microglobulin, GIP, leptin and others, a novel approach would be represented by a treatment capable of adequately removing these substances from the body of the patients. In this view, new polymers with biocompatible surface and high affinity for specific molecules have been developed and introduced to the market. Adsorption might in fact represent a new form of solute removal to be used in conjunction with the most sophisticated forms of renal replacement therapy. All the above-mentioned considerations have stimulated the collection of a series of manuscripts from worldwide experts in the field in an attempt to provide the reader of this book with a comprehensive summary of the most updated technology in the field of hemodialysis. New devices and new techniques are described and discussed in detail. The rationale for adsorptive therapies completes the analysis together with a series of preliminary results achieved with the most recent techniques. 
This volume contains some of the contributions presented during a technical forum organized by Karger Publishers on the occasion of the EDTA-ERA Congress hold in Nice, France, in September 2000. The book has been completed thanks to the scientific and organizational support of RenalTech International. To both these partners, we extend our sincere appreciation and gratitude for making the publication possible and of high quality.

Claudio Ronco

James F. Winchester 